\title{
Electrophoretic karyotype of Fusarium solani
}

\author{
Sarita W. Nazareth† and Carlo V. Bruschi \\ Author for correspondence: Carlo V. Bruschi. Tel: +39 403757304 . Fax: +39 403757343. \\ e-mail: bruschi@icgeb.trieste.it
}

Department of

Microbiology, International

Centre for Genetic

Engineering and

Biotechnology, Padriciano

99, I-34012 Italy

\begin{abstract}
The electrophoretic karyotype of Fusarium solani was determined by contourclamped homogeneous electric field (CHEF) gel electrophoresis. Thirteen chromosomal bands were obtained. The size of these bands, based on their migration relative to the chromosomal DNA of Schizosaccharomyces pombe and Saccharomyces cerevisiae, is estimated to be between 0.42 and $6.08 \mathrm{Mb}$, the total molecular size of the DNA being $39.90 \mathrm{Mb}$.
\end{abstract}

Keywords: Fusarium solani, electrophoretic karyotype, CHEF, chromosomes

\section{INTRODUCTION}

Fusarium species have gained importance because of their involvement in plant pathogenesis (Leary \& Endo, 1971; Kuhn \& Smith, 1978; Smith et al., 1982), production of plant hormones (Jeffreys, 1973), and lignin biodegradation (Norris, 1980; Sutherland et al., 1983). Fusarium solani (Mart.) Sacc., ATCC 64023, degrades ferulic acid, one of the monomeric lignin model compounds (Crawford, 1981), via decarboxylation to 4-vinylguaiacol, prior to its further oxidation (Nazareth \& Mavinkurve, 1986). This pathway is not commonly reported to occur in fungi. Little is known genetically about the species, which offers a wide scope for study; the determination of its genomic composition would be of significance.

CHEF gel electrophoresis has been successfully applied in resolution of the large chromosomal DNA (ChDNA) molecules of a number of fungi, such as Aspergillus spp. (Brody \& Carbon, 1989; Debets et al., 1990), Septoria nodorum (Cooley \& Caten, 1991), Neurospora crassa (Orbach et al., 1988), Saccharomyces cerevisiae, Candida albicans and Schizosaccharomyces pombe (Vollrath \& Davis, 1987; Magee \& Magee, 1987). ChDNA of Nectria baematococca was partially resolved by Miao et al. (1991), who reported the chromosomal locations of the cytochrome P-450 gene family in the organism. Using this technique, we report here the first complete electrophoretic karyotype of $F$. solani.

\footnotetext{
† Present address: Department of Microbiology, Goa University, Taleigao Plateau, Bambolim, Goa-403202, India.
}

Abbreviations: ChDNA, chromosomal DNA; CHEF, contour-clamped homogeneous electric field.

\section{METHODS}

Organism. Fusarium solani ATCC 64023 (Nazareth \& Mavinkurve, 1986), was cultured routinely on potato dextrose agar (PDA) or broth (PDB).

Preparation of intact chromosomal DNA. The culture was grown in PDB and conidia were harvested by filtration through cheesecloth. Conidia ( $4 \times 10^{8}$ as counted by a haemocytometer) were resuspended in PDB $(125 \mathrm{ml})$, and incubated on a rotary shaker at $30^{\circ} \mathrm{C}, 200$ r.p.m., for $3-4 \mathrm{~h}$, until the conidia had germinated with germ tubes 1-4 times the length of the conidium.

ChDNA was isolated by the agarose-spheroplast method of Orbach et al. (1988), with slight modifications. Germinated conidia (about $2 \times 10^{8}$ ) were mixed with molten $1 \%(\mathrm{w} / \mathrm{v}$ ) lowmelting-point agarose prepared in $0.125 \mathrm{M} \mathrm{EDTA} / 0.05 \mathrm{M}$ sodium citrate ( $\mathrm{pH} 5 \cdot 7$ ) containing Lysing Enzymes (Sigma), so that the final cell density was $2 \cdot 0 \times 10^{8} \mathrm{ml}^{-1}$, agarose concentration $0.6 \%$, and Lysing Enzymes $2.7 \mathrm{mg} \mathrm{ml}^{-1}$. Lysing enzymes from Trichoderma barzianum, containing cellulase, protease and chitinase, substituted the Novozym 234 preparation of Orbach et al. (1988). The cell/agarose mixture was pipetted out with an Eppendorf tip $(1000 \mu \mathrm{l})$ into the plug mould (Bio-Rad), and kept at $4{ }^{\circ} \mathrm{C}$ to gel. The plugs were then removed, put into $0.05 \mathrm{M}$ sodium citrate $(\mathrm{pH} 5.7) / 0.4 \mathrm{M}$ EDTA $(\mathrm{pH} 8.0) / 7.5 \%$ (v/v) 2-mercaptoethanol for spheroplast formation, and incubated at $37^{\circ} \mathrm{C}$ for $24 \mathrm{~h}$. Plugs were rinsed three times with $0.4 \mathrm{M}$ EDTA ( $\mathrm{pH} \mathrm{8.0)}$ ) and incubated for $24 \mathrm{~h}$ at $50^{\circ} \mathrm{C}$ in NDS buffer [0.5 M EDTA (pH 8.0), $0.01 \mathrm{M}$ Tris $/ \mathrm{HCl}$ $(\mathrm{pH} 9.5)$ and $1 \%(\mathrm{w} / \mathrm{v}) \mathrm{N}$-lauroylsarcosine] containing $2 \mathrm{mg}$ proteinase $\mathrm{K} \mathrm{ml}^{-1}$, to lyse the cells. Plugs were rinsed three times with $0.05 \mathrm{M}$ EDTA ( $\mathrm{pH} \mathrm{8.0)}$ ) at room temperature and stored at $4{ }^{\circ} \mathrm{C}$. ChDNA stored thus was stable for over a year.

ChDNA was also prepared by the liquid spheroplast method of Orbach et al. (1988). However, the agarose spheroplast method was preferred for its ease of preparation, and was used for all further analysis.

CHEF analysis. CHEF gel electrophoresis was performed in a CHEF-DR II system (Bio-Rad) fitted with a buffer-circulating pump in a cold room at $4{ }^{\circ} \mathrm{C}$. ChDNA agarose plugs were cut 

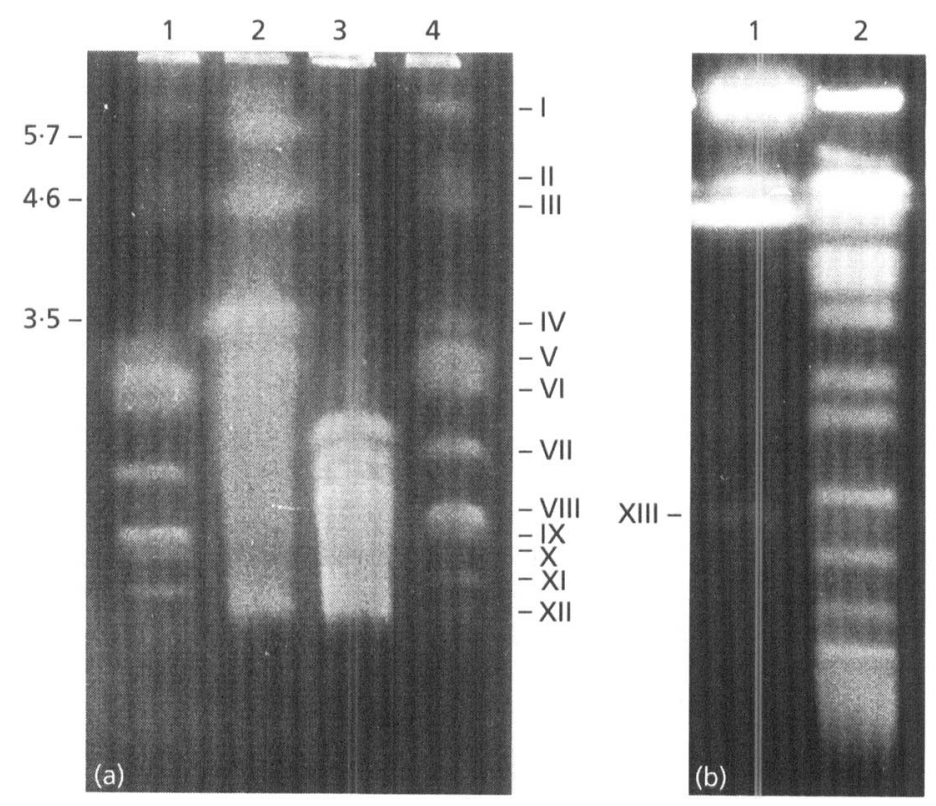

Fig. 1. Electrophoretic karyotype of $F$. solani by CHEF gel electrophoresis with run conditions of: (a) $60 \mathrm{~V}$, with switch intervals of $45 \mathrm{~min}$ for $52 \mathrm{~h}$, followed by $30 \mathrm{~min}$ for $68 \mathrm{~h}$; (b) $150 \mathrm{~V}$, with switch intervals of $60 \mathrm{~s}$ for $15 \mathrm{~h}$, followed by $90 \mathrm{~s}$ for $9 \mathrm{~h}$. Lanes: (a)

-0.461 and 4, F. solani; 2 , Sch. pombe; 3, Sacch. cerevisiae. The numbers on the left indicate

-0.37 the DNA size of the Sch. pombe chromosome standard in megabase pairs. (b) 1, F. solani; 2, Sacch. cerevisiae. The numbers on the right indicate the DNA size of two of the Sacch. cerevisiae chromosome standards in megabase pairs. Roman numerals indicate the individual chromosomal bands of F. solani. into blocks of $3 \mathrm{~mm}$ height (to fit into the gel well), each block containing approximately $10^{7}$ lysed germinated conidial cells. Gels of $0.7 \%$ chromosomal-grade agarose (Sigma) were run in $0.5 \times \mathrm{TBE}$ at $9^{\circ} \mathrm{C}$, as indicated in the Bio-Rad manual, along with standard ChDNA samples of $S c h$. pombe and Sacch. cerevisiae (Bio-Rad). The run conditions were varied as described in the results. The band sizes were determined by comparison with standard ChDNA samples.

\section{RESULTS AND DISCUSSION}

The molecular sizes of ChDNAs of F. solani extend over a fairly wide range and could not be resolved by any one set of electrophoretic conditions, but with appropriate run conditions the entire karyotype could be resolved by a combination of two runs. Resolution of large ChDNAs (Vollrath \& Davis, 1987) can be obtained only with long switch intervals for a prolonged time at a lowered voltage, while ChDNA intermediate in size requires a shorter switch interval. Thus the ChDNA of $F$. solani was separated mainly by a combined switch interval of $45 \mathrm{~min}$ for $52 \mathrm{~h}$ followed by $30 \mathrm{~min}$ for $68 \mathrm{~h}$, all at $60 \mathrm{~V}$. Twelve bands were obtained, of molecular sizes $6.08,4.95,4.60$, $3.45,3.22,3.05,2.72,2.45,2.39,2.32,2.17$ and $2.08 \mathrm{Mb}$ (Fig. 1a). The curving of lane 1 in Fig. 1(a) may be explained as being a result of the migration of bulky chromosomes, both of $F$. solani and of Sch. pombe in the adjacent lane. Hence the ChDNA migration pattern differs a little from that in lane 4 . Replicates of $F$. solani ATCC 64023 gave identical electrophoretic patterns. Observations were recorded for a minimum of three runs.

Using run conditions employed for separation of Sacch. cerevisiae $\mathrm{ChDNA}$, with a little modification, viz. a switch interval of $60 \mathrm{~s}$ for $15 \mathrm{~h}$ followed by $90 \mathrm{~s}$ for $9 \mathrm{~h}$, at $150 \mathrm{~V}$, a further band, corresponding to $0.42 \mathrm{Mb}$, was obtained (Fig. 1b). The above results indicate that $F$. solani has 13 chromosomes. Based on the ChDNA molecule sizes obtained, the total chromosomal DNA is calculated to be $39.90 \mathrm{Mb}$. Puhalla (1981) reported the chromosome number as being 4-7 in various Fusarium species, while Miao et al. (1991) described the presence of 10-15 ChDNAs in species of Nectria baematococca (the sexual state of Fusarium solani).

For many fungi there is little or no genetic data available, and electrophoretic karyotyping is one of the molecular tools, together with restriction fragment length polymorphism (RFLP), for analysis of variability/homology in fungi. Electrophoretic karyotyping is reported to show more variability than RFLP analysis (Magee \& Magee, 1987). Thus the electrophoretic karyotype of $F$. solani holds much scope for further genetic analysis and a better understanding of the genetic makeup of this organism.

\section{ACKNOWLEDGEMENTS}

This work was supported by a fellowship of the International Centre for Genetic Engineering \& Biotechnology-United Nations Industrial Development Organization. The technical assistance of S. Ugolini is gratefully acknowledged.

\section{REFERENCES}

Brody, H. \& Carbon, J. (1989). Electrophoretic karyotype of Aspergillus nidulans. Proc Natl Acad Sci US A 86, 6260-6263.

Crawford, R. L. (1981). Lignin Biodegradation and Transformation. New York: Wiley-Interscience.

Cooley, R. N. \& Caten, C. E. (1991). Variation in electrophoretic karyotype between strains of Septoria nodurum. Mol \& Gen Genet 228, $17-23$.

Debets, A. J. M., Holub, E. F., Swart, K., Van den Broek, H. W. J. \& Bos, C. J. (1990). An electrophoretic karyotype of Aspergillus niger. Mol \& Gen Genet 224, 264-268.

Jeffreys, E. G. (1973). The gibberellin fermentation. Adv Appl Microbiol 13, 283-315. 
Kuhn, P. J. \& Smith, D. A. (1978). Detoxification of the phytoalexin, kievetone, by Fusarium solani f. sp. phaseoli. Ann Appl Biol 89, 362-366.

Leary, J. V. \& Endo, R. M. (1971). A Fusarium induced root rot of staked tomatoes. Phytopathology 61, 900.

Magee, B. B. \& Magee, P. T. (1987). Electrophoretic karyotypes and chromosome numbers in Candida species. J Gen Microbiol 133, 425-430.

Miao, V.P. W., Matthews, D. E. \& VanEtten, H. D. (1991). Identification and chromosomal locations of a family of cytochrome P-450 genes for pisatin detoxification in the fungus Nectria baematococca. Mol \& Gen Genet 226, 214-223.

Nazareth, S. \& Mavinkurve, S. (1986). Degradation of ferulic acid via 4-vinylguaiacol by Fusarium solani (Mart.) Sacc. Can J Microbiol 32, 494-497.

Norris, D. M. (1980). Degradation of ${ }^{14} \mathrm{C}$-labeled lignins and ${ }^{14} \mathrm{C}$ labeled aromatic acids by Fusarium solani. Appl Environ Microbiol 40, 376-380.

Orbach, M. J., Vollrath, D., Davis, R. W. \& Yanofsky, C. (1988). An electrophoretic karyotype of Neurospora crassa. Mol Cell Biol 8, 1469-1473.

Puhalla, J. (1981). Genetic considerations of the genus Fusarium. In Fusarium: Diseases, Biology and Taxonomy, pp. 291-305. Edited by P. E. Nelson, T. A. Toussoun \& R. J. Cook. University Park, PA: Pennsylvania State University Press.

Smith, D. A., Harrer, J. M. \& Cleveland, T. E. (1982). Relation between production of extracellular kievitone hydratase by isolates of Fusarium and their pathogenicity on Pbaseolus vulgaris. Pbytopatbology 72, 1319-1323.

Sutherland, J. B., Pometto, A. L., III \& Crawford, D. L. (1983). Lignocellulose degradation by Fusarium species. Can $J$ Bot 61, 1194-1198.

Vollrath, D. \& Davis, R. W. (1987). Resolution of DNA molecules greater than 5 megabases by contour clamped homogeneous electric fields. Nucleic Acids Res 15, 7865-7876.

Received 6 December 1993; accepted 20 December 1993. 